\title{
Polyethylene Mulch Stimulates Early Root Growth and Nutrient Uptake of Transplanted Tomatoes
}

\author{
H.C. Wien ${ }^{1}$, P.L. Minotti' ${ }^{2}$ and V.P. Grubinger ${ }^{3}$ \\ Department of Fruit and Vegetable Science, Cornell University, Ithaca, NY 14853 \\ Additional index words. Lycopersicon esculentum, stem branching, stem temperature, soil temperature, phosphorus
}

\begin{abstract}
Tomato (Lycopersicon esculentum Mill.) plants grown on polyethylene (PE) mulch in New York State frequently have more branches and increased mineral nutrient uptake and yield than plants not mulched. In four field experiments conducted on a silt loam soil, clear PE mulch stimulated root extension shortly after transplanting. One week after transplanting, roots were significantly longer for mulched than for unmulched plants in all four experiments, whereas aboveground dry matter differences did not become significant until 14 days after transplanting in two of four trials. Mulching increased branching, hastened flowering on basal branches, and increased concentration of major nutrients in the aboveground parts. In the field, stimulation of aboveground growth due to mulch might be brought about by warming of the stem by air escaping from the planting hole in the mulch. However, an experiment with black, white, or clear mulch, in which the planting hole was either left uncovered or covered with soil, showed no effect of hole closure on branching even though air temperature near the stem was increased when holes were left uncovered. The results taken together imply that the increased aboveground growth observed with mulching is a consequence of enhanced root growth and nutrient uptake.
\end{abstract}

When tomato transplants are set in the field in New York State, soils are typically colder than optimum and low air temperatures may also limit plant growth. Research over the past few years (Wien and Minotti, 1987a, 1988b) has demonstrated the stimulating effects of PE mulch on aboveground growth, as expressed in flowering, branching, early and total fruit yields, and nutrient concentrations in the tops. Improved belowground conditions such as higher soil temperatures, optimal soil moisture levels, and reduced nutrient leaching are frequently given as reasons for the growth stimulation (Clarkson, 1960). Yet few authors have documented the effect of PE mulches on root growth (Knave1 and Mohr, 1967; Waggoner et al., 1960; Tindall et al., 1991), and none to our knowledge have reported an early stimulation of root growth by PE mulch. Such a phenomenon would be consistent with the observed increase in nutrient concentration and the finding that increased root zone temperature enhances root elongation (Maletta and Jones, 1987; Moorby and Graves, 1980). One of the objectives of the following experiments was to investigate the effect of PE mulch on root growth and dry matter increases of tomato during the first few weeks after transplanting. Top growth possibly may be stimulated by warm air escaping from the planting hole. We probed the linkage between branch growth and stem temperature differences generated by mulch and hole closure treatments in one experiment.

\section{Materials and Methods}

General. Tomato seeds were sown in Todd Planter Trays (Sun City, Fla.) of $80 \mathrm{ml}$ individual cell volume filled with peatvermiculite artificial soil mix. Seedlings were raised for $\approx 6$ weeks in a greenhouse and transplanted manually. In the field, a mixture of 4-amino-6-(1,1-dimethyl-ethyl)-3-[methylthiol-1, 2, 4-tria-

Received for publication 13 Jan. 1992. Accepted for publication 12 Sept. 1992. Cornell Univ. Dept. of Fruit and Vegetable Science paper no. 21. The cost of publishing this paper was defrayed in part by the payment of page charges. Under postal regulations, this paper therefore must be hereby marked advertisement solely to indicate this fact.

${ }^{1}$ Professor.

${ }^{2}$ Associate Professor.

${ }^{3}$ Former Graduate Assistant Current address: Univ. of Vermont Extension Service, Box 2430, Brattleboro, VT 05301.
zine-5(4H)-one](metribuzin) and $\alpha, \alpha, \alpha$, -trifluoro-2,6-dinitro$N-N$-dipropyl-p-toluidine (trifluralin) herbicides was sprayed over the experimental area at rates of 0.06 and $0.84 \mathrm{~kg} \cdot \mathrm{ha}^{-1}$, respectively, and lightly incorporated. Thereafter, clear PE mulch of 0.04 $\mathrm{mm}$ thickness and $122 \mathrm{~cm}$ width was applied by machine in rows $183 \mathrm{~cm}$ apart.

Mulch effects on root growth (Expts. 1 to 4). In four experiments conducted in 1987 and 1988, root and top growth of tomatoes were measured for 3 weeks after transplanting. The trials were planted on an Eel silt loam soil (fine-loamy, mixed, nonacid, mesic Aquic Udifluvent) on which $118 \mathrm{~kg} \mathrm{~N}, 52 \mathrm{~kg} \mathrm{P}$, and $98 \mathrm{~kg} \mathrm{~K} / \mathrm{ha}$ had been broadcast before plowing and harrowing. In Expts. 1 and 2, transplanted 29 May and 11 June 1987, respectively, the effect of bare soil or clear mulch was tested on the 'Revolution' and 'FM6203' tomatoes in a factorial treatment design. In Expts. 3 and 4, transplanted 3 and 15 June 1988, respectively, the mulching treatments of the previous year were repeated on 'Revolution' tomato. Individual plots in all experiments consisted of single rows $183 \mathrm{~cm}$ apart and $9.6 \mathrm{~m}$ long with in-row spacing of $46 \mathrm{~cm}$. Each experiment had a randomized complete-block design with four replications.

Root growth was estimated, using a modified trench profile method (Böhm et al, 1977) on samples taken weekly for 3 weeks after transplanting on three adjacent plants per plot. Trenches 140 $\mathrm{cm}$ long and $30 \mathrm{~cm}$ deep were dug by hand parallel to the row on each side of the mulched or unmulched plants, far enough away to not cut any of the roots. The trench sides near the plants were carefully excavated until the tips of the three longest roots of each plant were just visible. The length of these roots was then measured. No attempt was made to determine rooting depth, but informal observation indicated little deep root penetration, perhaps due to the presence of a plow pan and lower soil temperatures at greater depth. Aboveground dry matter was determined on the three plants used in root sampling.

Soil temperatures at $10 \mathrm{~cm}$ depth and air temperatures $10 \mathrm{~cm}$ above the plot surface were measured at hourly intervals during the first 3 weeks after planting using copper-constantan thermocouples connected to a Campbell model CR-5 recorder (Logan, Utah). The

Abbreviation: PE, polyethylene. 
Table 1. Length of the longest roots and aboveground dry weights of two tomato cultivars as influenced by clear PE mulch in two experiments in 1987. There were no significant cultivar $\times$ mulch interactions.

\begin{tabular}{|c|c|c|c|c|c|c|}
\hline \multirow[b]{3}{*}{ Variable } & \multirow{2}{*}{\multicolumn{3}{|c|}{$\begin{array}{c}\text { Root length } \\
\text { (centimeters from stem) }\end{array}$}} & \multirow{2}{*}{\multicolumn{3}{|c|}{$\begin{array}{c}\text { Dry wt/plant (g) } \\
\text { Sample date (WAT) }\end{array}$}} \\
\hline & & & & & & \\
\hline & 1 & 2 & 3 & 1 & 2 & 3 \\
\hline \multicolumn{7}{|c|}{ Expt. 1} \\
\hline \multicolumn{7}{|l|}{ Cultivar } \\
\hline Revolution & 15 & 25 & 37 & 2.0 & 4.2 & 14.1 \\
\hline FM6203 & 17 & 26 & 37 & 2.0 & 3.4 & 12.8 \\
\hline Significance & $*$ & $\mathrm{NS}^{\mathrm{y}}$ & NS & NS & $* y$ & NS \\
\hline \multicolumn{7}{|l|}{ Mulch } \\
\hline None & 13 & 19 & 29 & 1.8 & 3.2 & 8.4 \\
\hline Clear & 19 & 32 & 45 & 2.1 & 4.5 & 18.5 \\
\hline Significance & $* * *$ & $* *$ & $* * *$ & NS & $* *$ & $* * *$ \\
\hline \multicolumn{7}{|c|}{ Expt. 2} \\
\hline \multicolumn{7}{|l|}{ Cultivar } \\
\hline Revolution & 10 & 25 & & 1.3 & 4.6 & 14.5 \\
\hline FM6203 & 12 & 27 & & 1.3 & 5.2 & 14.2 \\
\hline Significance & NS & NS & & NS & NS & NS \\
\hline \multicolumn{7}{|l|}{ Mulch } \\
\hline None & 7 & 19 & & 1.0 & 3.2 & 7.9 \\
\hline Clear & 15 & 33 & & 1.5 & 6.5 & 20.9 \\
\hline Significance & $* * *$ & $* * *$ & & $* * *$ & $* * *$ & $* * *$ \\
\hline
\end{tabular}

$\overline{{ }^{2} \text { WAT }=\text { Weeks after transplanting; Expt. 1: 7, 13, and } 21 \text { days; Expt. 2: root length, } 7 \text { and } 14}$ days; dry matter, 8, 16, and 23 days.

${ }^{y}$ Only two replications sampled.

Ns,*,**,***Nonsignificant or significant at $P=0.05,0.01$, or 0.001 , respectively.

Table 2. Length of the longest roots and aboveground dry weights of 'Revolution' tomato as affected by clear PE mulch in two experiments in 1988.

\begin{tabular}{|c|c|c|c|c|c|c|}
\hline \multirow[b]{3}{*}{ Mulch } & \multirow{2}{*}{\multicolumn{3}{|c|}{$\begin{array}{c}\begin{array}{c}\text { Root length } \\
\text { (centimeters from stem) }\end{array} \\
\text { Sample data }(\mathrm{WAT})^{\mathrm{z}}\end{array}$}} & \multirow{2}{*}{\multicolumn{3}{|c|}{$\begin{array}{c}\text { Dry wt (g/plant) } \\
\text { Sample data (WAT) }\end{array}$}} \\
\hline & & & & & & \\
\hline & 1 & 2 & 3 & 1 & 2 & 3 \\
\hline \multicolumn{7}{|c|}{ Expt. 3} \\
\hline None & 4 & 8 & 15 & 3.2 & 4.6 & 9.3 \\
\hline Clear & 9 & 20 & 30 & 3.4 & 5.8 & 22.8 \\
\hline Significance & $* * *$ & $* * *$ & $* * *$ & NS & $*$ & $* * *$ \\
\hline \multicolumn{7}{|c|}{ Expt. 4} \\
\hline None & 7 & 17 & 21 & 3.4 & 9.0 & 19.4 \\
\hline Clear & 15 & 30 & 40 & 4.7 & 15.8 & 43.4 \\
\hline Significance & $* * *$ & $* * *$ & $* * *$ & $* * *$ & $* * *$ & $* * *$ \\
\hline
\end{tabular}

thermocouples in air were shaded by placement in the middle of Styrofoam cups.

Tissue samples for nutrient analysis were taken $\approx 2.5$ to 4 weeks after transplanting and consisted of the fifth or sixth whole leaf down from the top of the plant (Minotti et al, 1989). Samples from eight plants per experimental plot were dried, ground, and stored in airtight plastic bags at room temperature until subsamples were analyzed for total $\mathrm{N}$ and mineral element content by Kjeldahl and inductively coupled plasma-atomic emission spectroscopy, respectively (Grubiuger et al., 1992).

Branches longer than $5 \mathrm{~cm}$ were counted on five plants per plot in Expts. 1 and 2 at $\approx 3$ and 5 weeks after transplanting. Anthesis dates of first clusters on main stem and basal branches were recorded at 2-day intervals. In Expt. 3 and 4, ripe fruit were harvested from six plants per plot at weekly intervals and divided into marketable and cull categories. Separate counts were made of catfaced fruits, defined as fruits with blossom-end scars at least 1 cm long.

Stem temperature experiment. Expt. 5 was conducted on a Howard gravelly loam soil (loamy-skeletal, mixed mesic, Glossoboric Hapludalf) fertilized with $118 \mathrm{~kg} \mathrm{~N}, 52 \mathrm{~kg} \mathrm{P}$, and 98 $\mathrm{kg} \mathrm{K} / \mathrm{ha}$ broadcast before plowing and harrowing. Treatments 
consisted of mulching with black, white, or clear PE, or no mulch, and either covering the plant hole through the PE with soil or leaving it open. Mulch treatments in which the plant holes were covered had uncovered holes of the same size halfway between the plants in the row to equalize heat buildup under the mulch between closed and unclosed treatments. Seedlings of 'Revolution' tomato were transplanted 29 May. Treatments were arranged in a split plot treatment design, with mulches as main plots and hole closure treatments as subplots. Single-row plots were used, with seven plants per subplot, spaced $61 \mathrm{~cm}$ apart in the row. There were three replications.

Air temperatures were measured hourly in each plot for 1 month after transplanting with copper constantan thermocouples shielded by aluminum foil-covered white plastic tubes connected to the recorder previously described. Thermocouples were placed at the junction of mulch and stem in the uncovered hole plots and at $1 \mathrm{~cm}$ above the covered hole near the stem in the covered-hole treatments, as well as below the mulch ( $2 \mathrm{~cm}$ above soil surface) in all mulch treatments. Branches longer than $5 \mathrm{~cm}$ arising on the main stem were counted 4 weeks after transplanting. Anthesis dates of first clusters on main stem and basal branches were recorded at 2-day intervals.

\section{Results and Discussion}

Mulch effects on plant characteristics. In all four experiments,

Table 3. Branch number per plant and first anthesis dates of first main stem and fist basal branch clusters for two cultivars grown in two experiments in 1987 as influenced by clear PE mulch.

\begin{tabular}{|c|c|c|c|c|c|}
\hline \multirow[b]{3}{*}{ Cultivar } & \multirow[b]{3}{*}{ Mulch } & & & \multicolumn{2}{|c|}{$\begin{array}{c}\text { Flowering date } \\
(\text { WAT })^{\mathrm{y}}\end{array}$} \\
\hline & & \multicolumn{2}{|c|}{ Branches/plant ${ }^{\mathrm{z}}$} & \multirow{2}{*}{$\begin{array}{l}\text { Main } \\
\text { stem }\end{array}$} & \multirow{2}{*}{$\begin{array}{r}\text { Basal } \\
\text { - branch }\end{array}$} \\
\hline & & $3 \mathrm{WAT}^{\mathrm{y}}$ & $4 \mathrm{WAT}^{\mathrm{y}}$ & & \\
\hline & & \multicolumn{2}{|l|}{ Expt. 1} & & \\
\hline \multirow{2}{*}{ Revolution } & None & 0 & 6.5 & 18 & 40 \\
\hline & Clear & 1.3 & 8.8 & 17 & 36 \\
\hline \multirow[t]{2}{*}{ FM6203 } & None & 0.1 & 5.8 & 22 & 41 \\
\hline & Clear & 3.8 & 9.5 & 20 & 34 \\
\hline \multicolumn{2}{|l|}{ Interaction significance } & $*$ & NS & $* * *$ & NS \\
\hline \multirow{5}{*}{ Significance } & Cultivars & $*$ & NS & $* * *$ & NS \\
\hline & Mulch & $* * *$ & $* * *$ & NS & $* * *$ \\
\hline & & \multicolumn{2}{|l|}{ Expt. 2} & & \\
\hline & & \multicolumn{2}{|c|}{ Sample date $(\text { WAT })^{y}$} & & \\
\hline & & 3 & 5 & & \\
\hline \multirow[t]{2}{*}{ Revolution } & None & 0 & 8.5 & 20 & 38 \\
\hline & Clear & 3.2 & 9.2 & 20 & 34 \\
\hline \multirow[t]{2}{*}{ FM6203 } & None & 0.4 & 8.2 & 24 & 39 \\
\hline & Clear & 5.4 & 9.2 & 20 & 32 \\
\hline \multirow{3}{*}{$\begin{array}{l}\text { Interaction significance } \\
\text { Significance }\end{array}$} & & NS & NS & $*$ & $*$ \\
\hline & Cultivars & $*$ & NS & NS & NS \\
\hline & Mulch & $* * *$ & $*$ & $*$ & $* * *$ \\
\hline
\end{tabular}

Table 4. First anthesis dates of main stem and basal branch clusters and marketable and total yields of 'Revolution' tomato grown with or without clear PE mulch in 1988.

\begin{tabular}{|c|c|c|c|c|c|c|}
\hline \multirow[b]{3}{*}{ Mulch } & \multicolumn{2}{|c|}{ Flowering date $(\mathrm{DAT})^{\mathrm{z}}$} & & & & \\
\hline & \multirow{2}{*}{$\begin{array}{l}\text { Main } \\
\text { stem }\end{array}$} & \multirow{2}{*}{$\begin{array}{c}\text { Basal } \\
\text { branch }\end{array}$} & \multicolumn{2}{|c|}{ Marketable yield $\left(t \cdot h a^{-1}\right)$} & \multicolumn{2}{|c|}{ Total yield $\left(\mathrm{t} \cdot \mathrm{ha}^{-1}\right)$} \\
\hline & & & Early $^{y}$ & Total & Early $^{y}$ & Total \\
\hline \multicolumn{7}{|c|}{ Expt. 3} \\
\hline None & 18 & 45 & 8.2 & 34 & 10.1 & 73 \\
\hline Clear & 16 & 38 & 10.0 & 60 & 15.9 & 103 \\
\hline Significance & NS & $* * *$ & NS & $* * *$ & $* *$ & $* * *$ \\
\hline \multicolumn{7}{|c|}{ Expt. 4} \\
\hline None & 16 & 36 & 7.4 & 25 & 8.8 & 71 \\
\hline Clear & 14 & 32 & 12.0 & 36 & 14.7 & 97 \\
\hline Significance & NS & $* * *$ & $* * *$ & $* *$ & $* * *$ & $* *$ \\
\hline
\end{tabular}

${ }^{2} \mathrm{DAT}=$ days after transplanting.

Includes first three weekly harvests.

NS, $* * * * *$ Nonsignificant or significant at $P=0.01$ or 0.001 , respectively. 
plants growing on clear PE mulch showed a dramatic increase in root length over plants grown on bare soil (Tables 1 and 2). Within a week after transplanting, the roots of mulched plants were in every case significantly longer than those of unmulched plants. By week three, roots of mulched plants in Expt. 2 had reached the edge of the plastic mulch, and their unimpeded extension could no longer be measured. Mulch increased maximum soil temperature by 5 and $7 \mathrm{C}$ in the first week after transplanting in Expts. 1 and 2, respectively, with similar differences in Expts. 3 and 4. Combining the results of the four experiments, the rate of root extension between 1 and 2 weeks after transplanting was highly significantly correlated with soil temperature in week $1(\mathrm{y}=0.15 \mathrm{x}-1.57, r=$ $0.93, \mathrm{n}=8$ ).

The stimulation of aboveground growth by mulching occurred more slowly than the increase in root growth. In Expts. 1 and 3, dry weight of tops of plants grown on mulch did not exceed that of unmulched plants until 2 weeks after transplanting. The mulchinginduced dry matter differences were not significantly correlated with soil temperatures.

Mulching stimulated branch growth and hastened flowering on branches (Tables 3 and 4). The flowering response of the processing cultivar FM6203 to mulching was somewhat more pronounced than in 'Revolution', leading to a significant cultivar $\times$ mulch interaction. In previous experiments, clear PE mulch also increased flower cluster count more in a processing than in larger-fruited cultivars (Wien and Minotti, 1988b).

The mulch-induced growth stimulation was also reflected in higher early and total yields in Expts. 3 and 4 (Table 4). Marketable yields were much lower than total yields in both experiments because of a high incidence of small and cracked fruits. In addition, plants in Expt. 4 grown on mulch produced $41 \%$ catfaced fruits, compared to $22 \%$ for plants on bare ground. In Expt. 3, $17 \%$ of the fruits were catfaced, with no differences due to mulching treatment. The increase in catfacing incidence for mulch-grown plants has not been generally found in our experiments (Wien and Minotti, 1988a, 1988b). Possibly, clusters arising on basal branches, which were stimulated to develop early with the plastic mulch treatment, reached the susceptible stage of development in Expt. 4 just as plants were subjected to low temperatures in the field (Barten et al, 1992).

Concentrations of $\mathrm{N}, \mathrm{P}, \mathrm{K}, \mathrm{B}$, and $\mathrm{Cu}$ in plants grown on mulch were significantly higher than in plants not mulched in Expts. 1, 2, and 3 (Table 5). In addition, top growth at the final sampling time was increased more than 2-fold (Tables 1 and 2). Thus, early accumulation of these nutrients as measured by concentration $x$ plant dry weight was even- greater than the differences in top growth. Concentrations of $\mathrm{Ca}, \mathrm{Zn}$, and $\mathrm{Mn}$ were either less in mulched plants or not affected, while the effect of mulch on $\mathrm{Mg}$

Table 5. Nutrient concentration in the shoots of field-grown tomatoes as affected by PE mulch and cultivar.

\begin{tabular}{|c|c|c|c|c|c|c|c|c|c|}
\hline \multirow[b]{3}{*}{ Variable } & \multicolumn{9}{|c|}{ Nutrient concn in tomato shoots } \\
\hline & \multicolumn{5}{|c|}{ Percent dry wt } & \multicolumn{4}{|c|}{ ppm } \\
\hline & $\mathrm{N}$ & $\mathrm{P}$ & $\mathrm{K}$ & $\mathrm{Ca}$ & $\mathrm{Mg}$ & $\mathrm{Cu}$ & $\mathrm{B}$ & $\mathrm{Zn}$ & $\mathrm{Mn}$ \\
\hline \multicolumn{10}{|c|}{ Expt. 1: $1987(2.5 \text { WAT })^{z}$} \\
\hline \multicolumn{10}{|l|}{ Mulch } \\
\hline None & 3.01 & 0.22 & 1.76 & 4.79 & 0.46 & 6.4 & 26.0 & 14.1 & 80 \\
\hline Clear & 3.41 & 0.34 & 2.39 & 4.89 & 0.55 & 8.5 & 31.3 & 12.0 & 59 \\
\hline Significance & $*$ & $* * *$ & $* * *$ & NS & $* *$ & $* * *$ & $* *$ & $* *$ & $* * *$ \\
\hline \multicolumn{10}{|l|}{ Cultivar } \\
\hline Revolution & 3.06 & 0.25 & 2.08 & 4.47 & 0.44 & 7.4 & 24.8 & 11.9 & 61 \\
\hline FM 6203 & 3.37 & 0.31 & 2.06 & 5.16 & 0.58 & 7.5 & 32.2 & 13.9 & 78 \\
\hline Significance & $*$ & $* * *$ & NS & $* * *$ & $* * *$ & NS & $*$ & $*$ & $* * *$ \\
\hline Cultivar $\times$ mulch & NS & NS & $*$ & NS & * & NS & NS & NS & NS \\
\hline \multicolumn{10}{|c|}{ Expt. 2: $1987(3.5 \text { WAT })^{2}$} \\
\hline \multicolumn{10}{|l|}{ Mulch } \\
\hline None & 3.55 & 0.25 & 2.28 & 5.40 & 0.61 & 7.8 & 22.8 & 11.8 & 75 \\
\hline Clear & 3.91 & 0.34 & 3.07 & 4.94 & 0.64 & 10.1 & 25.1 & 12.2 & 70 \\
\hline Significance & $* * *$ & $* * *$ & $* * *$ & $*$ & NS & $* *$ & $*$ & NS & NS \\
\hline \multicolumn{10}{|l|}{ Cultivar } \\
\hline Revolution & 3.57 & 0.27 & 2.77 & 5.04 & 0.59 & 8.8 & 21.8 & 10.6 & 68 \\
\hline FM 6203 & 3.89 & 0.32 & 2.58 & 5.29 & 0.66 & 9.1 & 26.2 & 13.4 & 77 \\
\hline Significance & $* * *$ & $*$ & NS & NS & $*$ & NS & $* * *$ & $* * *$ & NS \\
\hline Cultivar $\times$ mulch & $* *$ & NS & NS & NS & NS & NS & NS & NS & NS \\
\hline \multicolumn{10}{|c|}{ Expt. 3: $1988(4.5 \text { WAT })^{2}$} \\
\hline No mulch & 3.50 & 0.25 & 2.60 & 4.13 & 0.53 & 8.5 & 22.7 & 20.8 & 94 \\
\hline Clear & 4.14 & 0.43 & 3.53 & 3.55 & 0.52 & 10.5 & 25.1 & 19.5 & 71 \\
\hline Significance & $* * *$ & $* * *$ & $* * *$ & $* *$ & NS & $* *$ & $*$ & NS & $* * *$ \\
\hline \multicolumn{10}{|c|}{ Expt. $4: 1988(4.5 \text { WAT })^{z, y}$} \\
\hline No mulch & 4.70 & 0.49 & 3.24 & 3.82 & 0.60 & 12.6 & 26.1 & 24.2 & 137 \\
\hline Clear & 4.58 & 0.54 & 3.83 & 3.13 & 0.52 & 12.2 & 26.0 & 22.6 & 109 \\
\hline Significance & NS & NS & $* * *$ & $* * *$ & $* * *$ & NS & NS & NS & $* *$ \\
\hline
\end{tabular}

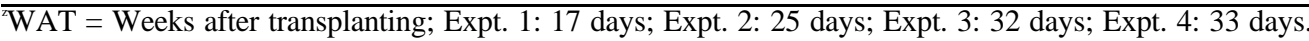

'Revolution' cultivar.

NS, $* * * * * *$ Nonsignificant or significant at $P=0.05,0.01$, or 0.001 , respectively. 
Table 6. Effect of mulching material and presence of an opening in the mulch at the plant stem on maximum and minimum air temperature near the stem and $2 \mathrm{~cm}$ above the soil surface on a sunny day in Expt. 5. ${ }^{2}$ There were no significant mulch $\times$ hole closure interactions.

\begin{tabular}{lcccc}
\hline & \multicolumn{4}{c}{ Temperature $\left({ }^{\circ} \mathrm{C}\right)$} \\
\cline { 2 - 5 } Variable & \multicolumn{2}{c}{ Minimum } & \multicolumn{2}{c}{ Maximum } \\
\cline { 2 - 5 } \cline { 2 - 5 } None & Stem $^{\mathrm{y}}$ & Surface $^{\mathrm{x}}$ & Stem $^{\mathrm{y}}$ & Surface $^{\mathrm{x}}$ \\
White & $13.4 \mathrm{a}$ & $13.4 \mathrm{a}$ & $30.3 \mathrm{a}$ & $34.9 \mathrm{a}$ \\
Black & $14.0 \mathrm{ab}$ & $14.7 \mathrm{~b}$ & $30.9 \mathrm{a}$ & $36.4 \mathrm{a}$ \\
Clear & $13.6 \mathrm{a}$ & $14.6 \mathrm{~b}$ & $35.4 \mathrm{~b}$ & $48.6 \mathrm{c}$ \\
Significance & $14.4 \mathrm{~b}$ & $15.7 \mathrm{c}$ & $31.0 \mathrm{a}$ & $41.6 \mathrm{~b}$ \\
& $* *$ & $* * *$ & $* * *$ & $* * *$ \\
Open & & Hole closure & & 39.8 \\
Closed & 13.9 & 14.6 & 33.0 & 40.9 \\
Significance & 13.7 & 14.5 & 30.8 & $\mathrm{NS}$ \\
& $\mathrm{NS}$ & $\mathrm{NS}$ & $*$ & \\
\hline
\end{tabular}

${ }^{\overline{2}}$ Means separation by Duncan's multiple range test at $P=0.05$.

'Air temperature near the stem, $\approx 5 \mathrm{~cm}$ above the soil surface.

${ }^{x}$ Air temperature $2 \mathrm{~cm}$ above the soil surface, under the mulch in mulched plots.

Ns, $* * *, * * *$ Nonsignificant or significant at $P=0.05,0.01$, and 0.001 , respectively.

concentrations was inconsistent among the experiments. Even in these cases, the total nutrient accumulation per plant was increased by mulch, since dilution by growth easily accounts for any concentration differences. The higher nutrient concentrations of $\mathrm{N}, \mathrm{P}$, $\mathrm{K}, \mathrm{Mg}, \mathrm{Zn}$, and $\mathrm{Mn}$ for unmulched plants in Expt. 4 compared to Expt. 3 are presumably due to enhanced uptake from warmer soils in the later planting (Table 5). Although mulching increased the $\mathrm{K}$ concentration in Expt. 4, in contrast to the other three field experiments, the concentrations of $\mathrm{N}, \mathrm{P}, \mathrm{B}$, and $\mathrm{Cu}$ were not affected. Nevertheless the increased top growth still resulted in increased accumulation per plant from mulching.

The increased concentration of $\mathrm{P}$ in leaf tissue of plants grown on clear PE mulch is consistent with our findings in earlier experiments (Grubinger et al, 1992; Wien and Minotti 1987; 1988a, 1988b). The mean soil temperature of 24C under the mulch during the first 2 weeks after transplanting in the 1987 root growth experiments was more nearly optimal for $\mathrm{P}$ uptake by tomatoes than the mean bare soil at 20C (Gosselin and Trudel, 1983; Tindall et al., 1991). In addition, more rapid extension of roots into the nutrient-rich upper soil layers due to mulching (Knave1 and Mohr, 1967; Tindall et al, 1991) would also maximize chances for efficient P uptake. Without PE, root growth was so restricted in the cool wet silt loam that plant $\mathrm{P}$ concentration in Expts. 1, 2, and 3 were in the possibly deficient range of $0.25 \%$ dry weight or less, even though adequate soil $\mathrm{P}$ levels of $14 \mathrm{mg} \cdot \mathrm{kg}^{-1}$ were measured before the start of the growing season (Grubinger et al., 1992). The mulch apparently stimulated root growth sufficiently to use the ample soil P supplies.

Stem temperature. Polyethylene mulch had the usual stimulating effect on plant growth and branching, as noted in previous experiments (data not shown). Air temperatures under the mulch, and resultant air temperatures near the stem, were not closely related to growth stimulation (Table 6). Although black PE caused the largest increases in temperature, branching and anthesis dates of first flowers on these branches were not hastened more than with white or clear mulch. Similarly, leaving the hole through which tomatoes were planted uncovered raised maximum stem temperature by $2.2 \mathrm{C}$ but produced no significant increase in branch growth. Hole closure also did not affect the nutrient concentration in the tops (data not shown).

The results thus rule out a direct influence of PE mulch on top growth through increased air temperatures around the plant. Similarly, the lack of a hole closure effect on branching and top growth argues against growth stimulation due to a possible $\mathrm{CO}_{2}$ enrichment of the air around mulched plants (Sheldrake, 1963). Lack of a chimney effect implies that the transplants need not be kept vertical directly above the hole in the mulch to obtain a mulch-induced growth stimulation.

The finding that early root growth is stimulated by PE mulch has several implications for fertilizer management of mulched plants. Fertilizer placement under the mulch is not critical, since roots extend rapidly laterally in the mulched area. Similarly, sidedressed $\mathrm{N}$ fertilizer can be placed at the edge of the PE mulch, since this research showed roots reaching that area by 3 weeks after planting.

\section{Literature Cited}

Barten, J.H.M., J.W. Scott, N. Kedar, and Y. Elkind. 1992. Low temperatures induce rough blossom-end scarring of tomato fruit during early flower development. J. Amer. Soc. Hort. Sci. 117:298-303.

Böhm, W., H. Maduakor, and H.M. Taylor. 1977. Comparison of five methods for characterizing soybean rooting density and development. Agron. J. 69:415-419.

Clarkson, V.A. 1960. Effect of black polyethylene mulch on soil and micro-climate temperature and nitrate level. Agron. J. 52:307-309.

Gosselin, A. and M.J. Trudel. 1983. Interactions between air and root temperatures on greenhouse tomato: II. Mineral composition of plants. J. Amer. Soc. Hort. Sci. 108:905-909.

Grubinger, V.P., P.L. Minotti, H.C. Wien, and A.D. Turner. 1992. Tomato response to starter fertilizer, polyethylenemulch and level of soil phosphorus. J. Amer. Soc. Hort. Sci. 118:212216.

Knavel, D.E. and H.C. Mohr. 1967. Distribution of roots of four different vegetables under paper and polyethylene mulches. Proc. Amer. Soc. Hort. Sci. 91:589-597.

Maletta, M. and H.W. Jones. 1987. Interrelation of root and shoot temperatures on dry matter accumulation and root growth in tomato seedlings. J. Hort. Sci. 6249-54.

Minotti, P.L., T.J. Hankinson, V.P. Grubinger, and H.C. Wien. 1989. Whole leaves versus petioles for assessing the nitrogen states of tomatoes. HortScience 24:84-86.

Moorby, J. and C.J. Graves. 1980. Root and air temperature effects on growth and yield of tomatoes and lettuce. Acta Hort. 98:29-42.

Sheldrake, R. 1963. Carbon dioxide levels in the microclimate as influenced by the permeability of mulches. Proc. Natl. Plastics Conf. 493-96.

Tindall, J.A., R.B. Beverly, and D.E. Radcliffe. 1991. Mulch effect on soil properties and tomato growth using micro-irrigation. Agron. J. 83:1028-1034.

Waggoner, P., P.M. Miller, and H.C. DeRoo. 1960. Plastic mulching, principles and benefits. Connecticut Agr. Expt. Sta. Bul. 634

Wien, H.C. and P.L. Minotti. 1987. Growth, yield and nutrient uptake of transplanted freshmarket tomatoes as affected by plastic mulch and initial nitrogen rate. J. Amer. Soc. Hort. Sci. 112:759-763.

Wien, H.C. and P.L. Minotti. 1988a. Response of fresh-market tomatoes to nitrogen fertilizer and plastic mulch in a short growing season. J. Amer. Soc. Hort. Sci. 113:61-65.

Wien, H.C. and P.L. Minotti. 1988b. Increasing yield of tomatoes with plastic mulch and apex removal. J. Amer. Soc. Hort. Sci. 113:342-347. 